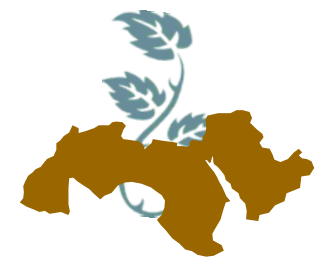

\title{
VARIETAL VARIATIONS OF SESAME IN NITROGEN UTILIZATION EFFICACY
}

\author{
Noha S. El-Khouly, Saudy H.S. and Abd El-Momen W.R. \\ Agronomy Dept., Fac. of Agric., Ain Shams Univ., P.O. Box 68 Hadayek Shoubra 11241, \\ Cairo, Egypt
}

Keywords: Sesame, Seed yield response index, Nitrogen; Variety

\begin{abstract}
From an eco-economic perspective, the efficient use of nitrogen is becoming incrementally worthwhile in crop management. Therefore, growth, yield and seed yield response index of three sesame varieties (Shandwel-1, Giza-32 and Sohag-1) as affected by four $\mathrm{N}$ rates $(0,72,108$ and $144 \mathrm{~kg} \mathrm{~N}^{-1}$ ) were investigated during two seasons of 2013 and 2014. The study illustrated that Sohag-1 was the superior variety for achieving SPAD value and seed yield $\mathrm{ha}^{-1}$. Sesame plants can be fertilized with $\mathrm{N}$ at a rate of $108 \mathrm{~kg}$ $\mathrm{ha}^{-1}$ being recorded higher seed yield ha ${ }^{-1}$. Integration between proper variety as a genetic factor with the appropriate $\mathrm{N}$ rate applied as an environmental one, i.e. Sohag-1 x $108 \mathrm{~kg} \mathrm{~N}^{-1}$ (or Sohag-1 x $144 \mathrm{~kg} \mathrm{~N}^{-1}$ ) considered a marked practice for gaining high sesame seed yield as an economic product. Being Sohag-1 exhibited less reduction in yield under low $\mathrm{N}$ rate and highly response with high $\mathrm{N}$ applied it belongs to ER group.
\end{abstract}

\section{INTRODUCTION}

Sesame is one of the oldest and most important oilseed crops in the world due to its high oil content and quality (Ashri, 1998). Sesame seed is also rich in proteins, vitamins, niacin, minerals and lignans and is popularly used as a food and medical purposes (Nakimi, 1995). In several developing countries, sesame is a crucial and cash edible oilseed crop particularly for smallholders. In Egypt, sesame is a food crop rather than oilseed one being most of its seed production is directly used for

(Received 6 February, 2018)

(Revised 19 February, 2018)

(Accepted 21 February, 2018) manufacture products, but it has low yield potentiality.

Cultivating the appropriate and high yielding variety and supplying with proper addition of $\mathrm{N}$ amount regarded the core practices for boosting crop productivity. Yield of sesame is highly variable depending upon the environmental factors, cultural patterns and cultivars used (Ali et al 2016). Despite the vital role of nitrogen in plant development and metabolism of carbohydrates and protein, neither excess nor paucity of it is useful for crop productivity. Convenient supply of nitrogen is salutary for carbohydrates and protein metabolisms as well ass cell division and enlargement, resulting in more leaf area, crop growth rate, leaf area index and thus ensuring good seed and dry matter yield (Ahmad et al 2001 and Ahmad et al 2002). The positive response of leaves number to $\mathrm{N}$ supply may have led to increase in photosynthetic activity thereby resulting in the enhancement of morphological traits via produced more branches and simultaneously enhanced pod production and thus increased yield (Shehu et al 2009). Accordingly, soil of low $\mathrm{N}$ content should be supply additional fertilizer in proper amount to make sure for better production. Until then, it has not been conclusively defined the required quantity of nitrogen for sesame plant. Okpara et al (2007) explained that sesame nurture remained very argumentative for long time, while some researchers are of the opinion that sesame does not require fertilization, others believe that the crop needed to be fertilized. In this situation, Haruna (2011b) and Shilpi et al (2012) reported substantially increased yield with increasing $\mathrm{N}$ up to $60 \mathrm{~kg} \mathrm{ha}^{-1}$. Excess nitrogen fertilizer application than $60 \mathrm{~kg} \mathrm{ha}^{-1}$ decreased seed yield (Shirazy et al 2017). N application up to $80 \mathrm{~kg}$ $\mathrm{ha}^{-1}$ caused a marked increase in leaves number, shoot dry weight and leaf area index (Umar et al 
2012) as well as seed yield and oil \% (Malik et al 2003). However, increasing $N$ from 0 up to $200 \mathrm{~kg}$ $\mathrm{ha}^{-1}$ showed increases in seed yield plant $^{-1}$ and seed yield ha ${ }^{-1}$ (El-Nakhlawy and Shaheen, 2009).

Choosing the compatible variety with the soil nutritional status is one of the most significant and costless for farmers. Moreover, exploiting genotypic differences in absorption and utilization of $\mathrm{N}$ to get better $\mathrm{N}$ fertilizer use and to attain higher productivity from soil that is deficient in nitrogen have delivered wide attention. Gaining varieties with high $\mathrm{N}$ utilization and with low fertilizer requirement would be appropriate to the crop production process (Le Gouis et al 2000). Improving nitrogen use efficiency (NUE) represents an important part of crop management for reducing the production costs and eschewing the nitrate pollution of waters, soils and harvest products (Silspoor and Momayezi, 2006). Discriminations in
NUE among sesame varieties have been recorded (Umar et al 2012).

Taken such points in account, the current study was carried out to evaluate the efficient use of nitrogen of three sesame varieties and determine the economic rate of nitrogen according to productivity.

\section{MATERIALS AND METHODS}

\section{Experimental site}

A 2-year field experiment was conducted during 2013 and 2014 seasons at the Research and Experimental Station Farm, Faculty of Agriculture $\left(30^{\circ} 19^{\prime} \mathrm{N}, 31^{\circ} 16^{\prime} \mathrm{E}\right)$, Ain Shams Univ., at Shalakan, Kalubia Governorate, Egypt. The soil of the experimental site was clay loam and its properties are presented in Table 1. The preceding crop was Egyptian clover in both seasons.

Table 1. Soil properties of the Research and Experimental Station at Shalakan

\begin{tabular}{|c|c|c|c|c|c|c|}
\hline Clay & $\begin{array}{l}\text { Silt } \\
(\%) \\
\end{array}$ & Sand & $\mathrm{pH}$ & $\begin{array}{c}E C \\
\left(\mathrm{dS} \mathrm{m}^{-1}\right)\end{array}$ & $\begin{array}{c}\text { Total } \\
\mathrm{N}\end{array}$ & $\begin{array}{r}\text { Organic } \\
\text { matter } \\
\left(\%, w^{-1}\right)\end{array}$ \\
\hline 56 & 29 & 15 & 7.84 & 1.48 & 0.33 & 1.41 \\
\hline
\end{tabular}

\section{Treatments and experimental design}

In factorial randomized complete block design with four replications, the performance of three sesame varieties (Shandwel-1, Giza-32 and Sohag-1) to four nitrogen fertilizer rates i.e. 0,72 , 108 and $144 \mathrm{~kg} \mathrm{~N} \mathrm{ha}^{-1}$, ammonium sulphate $(20.6 \% \mathrm{~N})$ was evaluate. Treatments involved $\mathrm{N}$ were applied into three equal portions, after thinning, before the second and the third irrigation, respectively. The experimental plot size was 10.5 $\mathrm{m}^{2}$ containing 5 ridges $(3.5 \mathrm{~m}$ length and $60 \mathrm{~cm}$ apart).

\section{Implementations}

Seeds of sesame varieties were sown in May 30 and 26 in the $1^{\text {st }}$ and $2^{\text {nd }}$ seasons, respectively, in hills (4-6 seeds per each) $20 \mathrm{~cm}$ apart on the ridge, then sowing irrigation was done. At 25 days after sowing (DAS), plants were thinned to secure two plants per hill followed by irrigation. Phosphorus fertilizer (in the form of calcium super phosphate, $\left.15 \% \mathrm{P}_{2} \mathrm{O}_{5}\right)$ was applied during the soil preparation at a rate of $240 \mathrm{~kg} \mathrm{ha}^{-1}$. All other recommended cultural practices for growing sesame were adopted throughout the two seasons.

\section{Data record}

At 45 DAS, total chlorophyll content (SPAD value) of the fourth leaf was determined by chlorophyll meter (SPAD 502) according to Soil Plant Analysis Department Section, Minolta Camera Co., Osaka, Japan as reported by Minolta (1989). Moreover, plant height was recorded at 75 DAS from five guarded plants of each plot.

At harvest, sampling of ten guarded plants was done across one middle ridge of each plot for measuring fruiting zone length and capsule number plant ${ }^{-1}$. Pods from all the other plants from the middle ridge excluding the sampled were harvested, threshed and weighed for seed yield. Seed yield $\mathrm{ha}^{-1}$ was calculated based on $9 \%$ moisture content. Seed oil and protein contents were determined according to A.O.A.C. (1995), then oil and protein yield ha ${ }^{-1}$ were computed. 
In addition and according to Fageria and Barbosa Filho (1981), seed yield response index (SYRI) was calculated for each variety as follow:

$S Y R I=\frac{\begin{array}{c}\text { Seed yield under high N rate }- \\ \text { Seed yield under low N rate }\end{array}}{\text { High N rate }- \text { Low N rate }}\left(\begin{array}{c}(\mathrm{kg} \mathrm{seeds} \\ \left.\mathrm{kg} \mathrm{N} N^{-1}\right)\end{array}\right.$
Where:
Low $\mathrm{N}$ rate $=0 \mathrm{~kg}^{-1}$
High $\mathrm{N}$ rate $=144 \mathrm{~kg} \mathrm{ha}^{-1}$

\section{Statistical analysis}

Data were subjected to analysis of variance (ANOVA) according to Gomez and Gomez (1984), using MSTATC software program. The combined analysis of variance for the data of the two seasons was performed after testing the error homogeneity. Duncan's multiple range test at 0.05 probability level was used for comparing among means.

\section{RESULTS AND DISCUSSION}

\section{Growth and yield traits}

Significant variations in growth and yield attributes among sesame varieties were obtained (Table 2). In this regard, Sohag-1 variety was the superior for achieving the maximum SPAD value, plant height, fruiting zone length, capsule number plant $^{-1}$ and seed yield and statistically at par with Giza-32 for the second, third and fourth former traits. The different performance of Shandwel-1, Giza-32 and Sohag-1 varieties in growth and yield traits could be attributed to their different genetic makeup plus utilization ability of growth factors prevailing in the experimental site. Moreover, the higher leaf greenness of Sohag-1 leaves (Table 2) might have help it to absorb more solar radiation which could have led to increased assimilate production and consequently higher seed yield was achieved. The superiority of a variety in growth could be reflected in improving yield attributes, then enhancing the economic yield. Similar varietal behaviors of sesame varieties were earlier reported by Kathiresan (2002); Saudy and Abd ElMomen (2009) and Kashani et al (2014).

Regarding the effect of $\mathrm{N}$ rates on growth and yield traits, data in (Table 2) revealed that the differences in SPAD value and plant height due to fertilizing sesame plants with 72,108 or $144 \mathrm{~kg} \mathrm{~N}$ $\mathrm{ha}^{-1}$ treatments did not reach the level of significance but surpassing the control one $\left(0 \mathrm{~kg} \mathrm{~N} \mathrm{ha}^{-1}\right)$. On the other hand, the longest fruiting zone was recorded with 72 , along with $144 \mathrm{~kg} \mathrm{~N} \mathrm{ha}^{-1}$.
Furthermore, fertilizing sesame plants resulted in significant increases in capsule number plant ${ }^{-1}$ and seed yield $\mathrm{ha}^{-1}$. In this respect plots received 108 or $144 \mathrm{~kg} \mathrm{~N}$ ha $^{-1}$ gave the highest values. This result clarifies that to ensure access to plentiful yield, sesame crop can be fertilized with $\mathrm{N}$ at a rate of $108 \mathrm{~kg} \mathrm{ha}^{-1}$ (Table 2). Such finding might be due to more accumulation of nitrogenous substances and better translocation of photosynthates to reproductive organs, thereby efficient seed filling. Kalaiselvan et al (2001) indicated that plant height, dry matter, and seed yield of sesame has increased significantly with an increase in nitrogen up to $150 \mathrm{~kg} \mathrm{ha}^{-1}$ for the former two traits, and up to $120 \mathrm{~kg} \mathrm{ha}^{-1}$ for the latter one. Additionally, relative to the control (without $\mathrm{N}$ fertilizer), application of $108 \mathrm{~kg} \mathrm{ha}^{-1}$ as a promising treatment caused $44.0 \%$ increase in seed yield versus $38.7 \%$ due to $144 \mathrm{~kg} \mathrm{~N} \mathrm{ha}^{-1}$ referring to, in this case, well applied $\mathrm{N}$ utilization by sesame plants. Moreover, redundant application of $\mathrm{N}$ using $144 \mathrm{~kg} \mathrm{~N}^{-1}$ did not achieve addition significant enhancement for seed yield than $108 \mathrm{~kg} \mathrm{~N} \mathrm{ha}^{-1}$. Thus saving $25 \%$ of $\mathrm{N}$ by applying $108 \mathrm{~kg} \mathrm{~N}^{-1}$ regarded a wise $\mathrm{N}$-use in sesame. Optimal level of nitrogen (which will be effectively and efficiently utilized), should be applied to sesame, in order to prevent undue loading of soils with chemicals and for improved crop performance and occurrence of environment friendliness conditions via improved soil and water quality (Babajide and Oyeleke, 2014). Our findings are in good harmony with Fathy and Mohammed (2009); Sarkar et al (2010); Haruna and Aliyu (2011a) and Jamdhade et al (2017).

Several combinations between varieties and $\mathrm{N}$ rates possessed noticeable enhancements in growth and yield attributes of sesame as presented in (Table 2). It could be noted that despite sesame varieties differed in their responses to increasing $\mathrm{N}$ rate, $\mathrm{N}$ application tended to has a positive effect of all estimated traits. The superior yielding treatment is Sohag-1 when fertilized with $108 \mathrm{~kg} \mathrm{~N}$ $\mathrm{ha}^{-1}$. Such treatment exceeded other ones except that of the same variety but fertilized with $144 \mathrm{~kg} \mathrm{~N}$ $\mathrm{ha}^{-1}$. Such superiority may be regarded as a reflection of the recorded enhancements in growth and yield attributes (Table 2). Coupling suitable variety as a genetic factor with the appropriate $\mathrm{N}$ level used as an environmental one, i.e. Sohag- 1 x 108 $\mathrm{kg} \mathrm{N} \mathrm{ha}{ }^{-1}$ considered a marked practice for attaining high sesame seed yield as an economic product. 
Table 2. Growth, yield and yield attributes of sesame varieties as affected by $\mathrm{N}$ levels

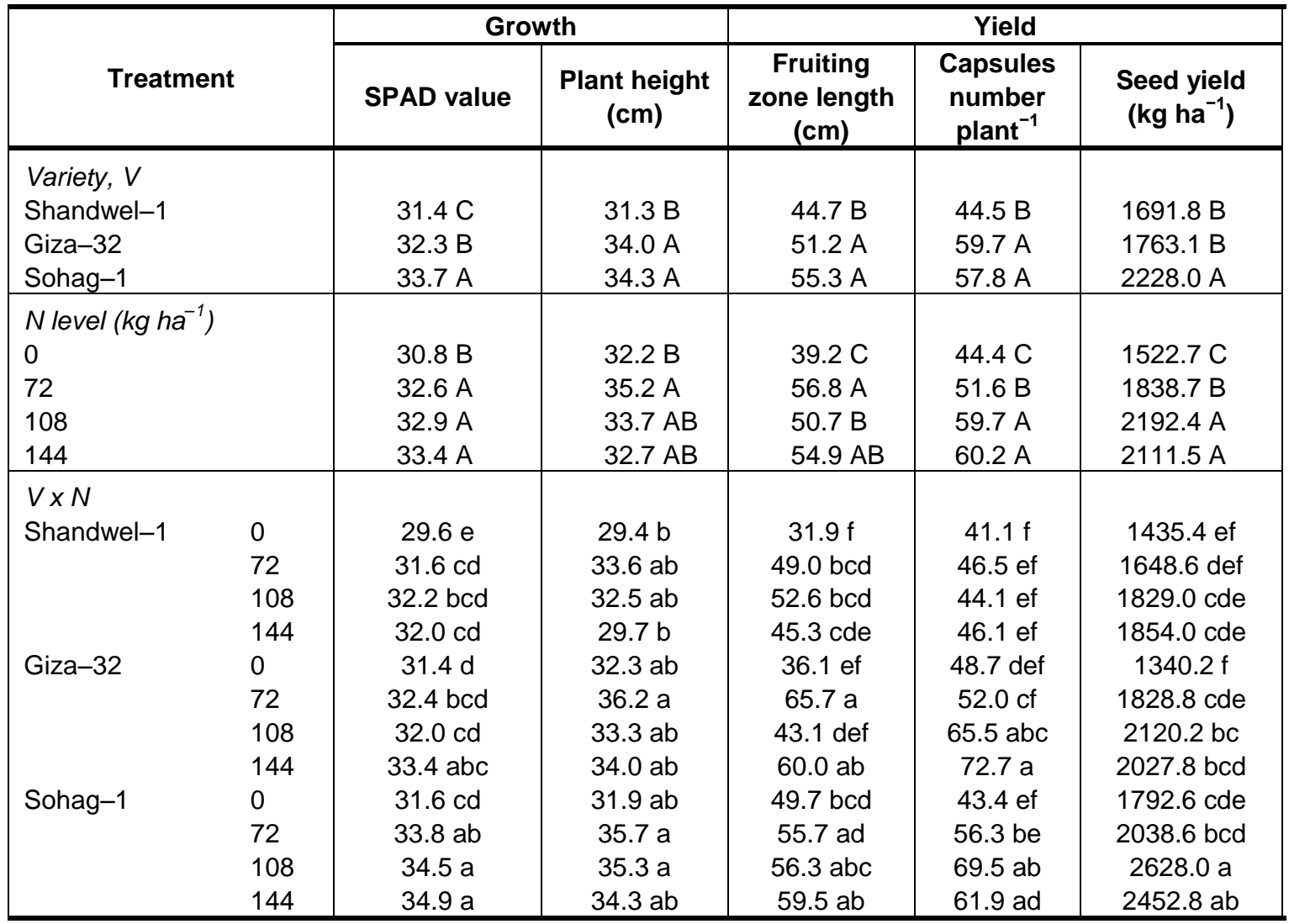

Different letters in the column indicate significant differences at $P<0.05$ using Duncan's multiple range test.

\section{Seed chemical traits}

The substantial differences in seed oil and protein $\%$ and yields among sesame varieties indicated that Sohag-1 was the potent variety for recording the highest values (Table 3). On the other hand, only yields (not percentages) of oil and protein were markedly affected by $\mathrm{N}$ rates. In this regard, addition of $108 \mathrm{~kg} \mathrm{~N}^{-1}$ was sufficient for sesame plants to produce the highest values and exceeding other $\mathrm{N}$ rates, ranging from $6.2-48.2 \%$ in oil yield and $12.9-46.8 \%$ in protein yield. The enhancements in oil and protein yields of Sohag-1 and due to application of $108 \mathrm{~kg} \mathrm{~N} \mathrm{ha}^{-1}$ might be mainly attributed to increasing seed yield (Table 2). Increasing nitrogen up to $120 \mathrm{~kg} \mathrm{ha}^{-1}$ achieved significant increase in sesame oil yield (Kalaiselvan, et al 2001).

Seeds of Sohag-1 with any $\mathrm{N}$ rate (for oil and protein \%) in addition to seeds of Giza-32 with 0 or $108 \mathrm{~kg} \mathrm{~N} \mathrm{ha}^{-1}$ (for protein \%) contained the maxi- mal values surpassing the other combinations (Table 3). Being the interaction of Sohag-1 $\times 108 \mathrm{~kg}$ $\mathrm{N}$ ha $^{-1}$ achieved the highest seed yield (Table 2), it also out yielded as expected the highest increases in oil and protein yields.

\section{Seed yield response index (SYRI)}

SYRI as an indicator to the efficient of plant varieties for attaining higher seed yield at low $\mathrm{N}$ rate $\left(0 \mathrm{~kg} \mathrm{~N} \mathrm{ha}^{-1}\right)$ and their response to high $\mathrm{N}$ rate (144 $\mathrm{kg} \mathrm{N} \mathrm{ha}^{-1}$ ) was calculated (Fig. 1). Accordingly, and as described by Fageria and Barbosa Filho (1981), it is possible to assort varieties into four categories: (i) efficient and responsive (ER) that attain high seed yield at low as well as high rates of $\mathrm{N}$ fertilizer; (ii) efficient and not responsive (ENR) that attain high seed yield at low $\mathrm{N}$ rate with lower response to increase $\mathrm{N}$ fertilizer than $\mathrm{ER}$; (iii) not efficient but responsive (NER) that has low seed yield with response to increase $\mathrm{N}$ fertilizer; 
and (iv) neither efficient nor responsive (NENR) that has low seed yield with low response to increase $\mathrm{N}$ fertilizer. Therefore, (Fig. 1) illustrated that Sohag-1 belongs to ER group being excelled the averages of seed yield at zero rate and SYRI, while Giza-32 was NER being gave lower seed yield at zero $\mathrm{N}$ rate and higher SYRI than the averages. Unlike, Shandwel-1 was NENR, where both seed yield at zero $\mathrm{N}$ rate and SYRI were lower than the averages. Such findings proved the differences among sesame varieties for absorbing and utilizing $\mathrm{N}$ in case of each of well $\mathrm{N}$ supply and from $\mathrm{N}-$ deficit soils. Sohag-1 exhibited less reduction in yield under low $\mathrm{N}$ rate and highly response with high $\mathrm{N}$ applied indicating the constancy and significance of focusing on this variety as an efficient gene pool to incorporate the adaptation for low $\mathrm{N}$ availability (in the soil) and with high efficiency in the utilization of $\mathrm{N}$ fertilizer applied. At low $\mathrm{N}$ supply, differences among varieties for SYRI were largely due to variation in utilization of accumulated $\mathrm{N}$, but with high $\mathrm{N}$, they were largely due to variation in uptake efficiency (Sattelmacher et al 1994). Increasing nitrogen rate significantly reduced NUE and that crop response and nutrient uptake tend to decrease significantly as excess nitrogen applied (Akintoye et al 1998 and Babajide and Oyeleke, 2014). Adding $100 \mathrm{~kg} \cdot \mathrm{ha}^{-1} \mathrm{had}$ the highest NUE exceeding that of $200 \mathrm{~kg} \cdot \mathrm{ha}^{-1}$ by $42.4 \%$ as well as the likely reason for lower NUE at higher $\mathrm{N}$ levels is the loss of $\mathrm{N}$ through sublimation, denitrification, leaching or the inability of the plants in $\mathrm{N}$ uptake (Jouyban et al 2011).

Table 3. Oil and protein \% and yields of sesame varieties as affected by $\mathrm{N}$ levels

\begin{tabular}{|c|c|c|c|c|c|}
\hline \multirow{2}{*}{\multicolumn{2}{|c|}{ Treatment }} & \multicolumn{2}{|c|}{ Oil } & \multicolumn{2}{|c|}{ Protein } \\
\hline & & $\%$ & $\begin{array}{c}\text { Yield } \\
\left(\mathrm{kg} \mathrm{ha}^{-1}\right)\end{array}$ & $\%$ & $\begin{array}{c}\text { Yield } \\
\left(\mathrm{kg} \mathrm{ha}^{-1}\right)\end{array}$ \\
\hline \multicolumn{2}{|l|}{ Variety, V } & & & & \\
\hline \multicolumn{2}{|l|}{ Shandwel-1 } & $51.4 \mathrm{~B}$ & $868.7 \mathrm{C}$ & $23.4 \mathrm{~B}$ & $394.8 \mathrm{C}$ \\
\hline \multicolumn{2}{|l|}{ Giza-32 } & $50.0 \mathrm{~B}$ & 915.2 B & $25.9 \mathrm{~A}$ & $471.1 \mathrm{~B}$ \\
\hline \multicolumn{2}{|l|}{ Sohag-1 } & $54.6 \mathrm{~A}$ & $1220.8 \mathrm{~A}$ & $27.0 \mathrm{~A}$ & $602.1 \mathrm{~A}$ \\
\hline \multicolumn{2}{|c|}{ N level $\left(\mathrm{kg} \mathrm{ha}^{-1}\right)$} & & & & \\
\hline \multicolumn{2}{|l|}{0} & $51.5 \mathrm{~A}$ & $787.4 \mathrm{D}$ & $26.0 \mathrm{~A}$ & $396.1 \mathrm{D}$ \\
\hline \multicolumn{2}{|l|}{72} & $51.9 \mathrm{~A}$ & $954.1 \mathrm{C}$ & $25.2 \mathrm{~A}$ & $464.6 \mathrm{C}$ \\
\hline \multicolumn{2}{|l|}{108} & $52.9 \mathrm{~A}$ & $1166.7 \mathrm{~A}$ & $26.2 \mathrm{~A}$ & $581.6 \mathrm{~A}$ \\
\hline \multicolumn{2}{|l|}{144} & $51.7 \mathrm{~A}$ & $1098.1 \mathrm{~B}$ & $24.3 \mathrm{~A}$ & $515.1 \mathrm{~B}$ \\
\hline \multicolumn{6}{|l|}{$V \times N$} \\
\hline \multirow[t]{4}{*}{ Shandwel-1 } & 0 & $51.0 \mathrm{bc}$ & $732.1 \mathrm{~g}$ & $23.2 \mathrm{~cd}$ & $333.0 \mathrm{i}$ \\
\hline & 72 & $53.1 \mathrm{ab}$ & $875.4 f$ & $24.2 \mathrm{bcd}$ & $399.0 \mathrm{ghi}$ \\
\hline & 108 & $51.0 \mathrm{bc}$ & 932.8 def & $22.9 \mathrm{~d}$ & $418.8 \mathrm{fgh}$ \\
\hline & 144 & $50.4 \mathrm{bc}$ & 934.4 def & $23.1 \mathrm{~d}$ & $428.3 \mathrm{eh}$ \\
\hline \multirow[t]{4}{*}{ Giza-32 } & 0 & $50.2 \mathrm{bc}$ & $672.8 \mathrm{~g}$ & $27.7 a b$ & $371.2 \mathrm{hi}$ \\
\hline & 72 & $49.0 \mathrm{c}$ & 896.1 ef & $25.3 \mathrm{bcd}$ & $462.7 \mathrm{efg}$ \\
\hline & 108 & $51.8 \mathrm{bc}$ & $1098.3 \mathrm{c}$ & $26.6 \mathrm{ad}$ & $564.0 \mathrm{c}$ \\
\hline & 144 & $49.0 \mathrm{c}$ & $993.6 \mathrm{~d}$ & $24.0 \mathrm{bcd}$ & $486.7 \mathrm{de}$ \\
\hline \multirow[t]{4}{*}{ Sohag-1 } & 0 & $53.4 a b$ & $957.2 \mathrm{de}$ & $27.0 \mathrm{abc}$ & 484.0 def \\
\hline & 72 & $53.5 a b$ & $1090.7 \mathrm{c}$ & $26.1 \mathrm{ad}$ & $532.1 \mathrm{~cd}$ \\
\hline & 108 & $55.9 \mathrm{a}$ & $1469.1 \mathrm{a}$ & $29.0 \mathrm{a}$ & $762.1 \mathrm{a}$ \\
\hline & 144 & $55.7 \mathrm{a}$ & $1366.2 \mathrm{~b}$ & $25.7 \mathrm{ad}$ & $630.4 \mathrm{~b}$ \\
\hline
\end{tabular}

Different letters in the column indicate significant differences at $\mathrm{P}<0.05$ using Duncan's multiple range test 


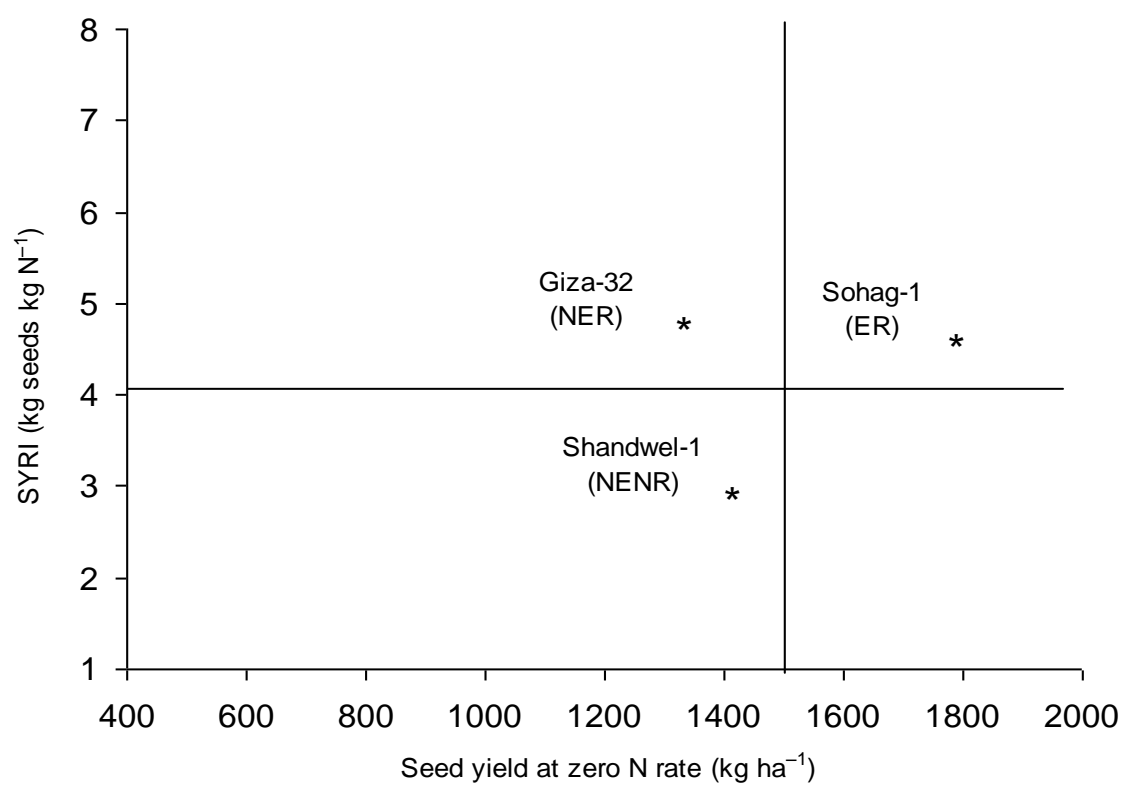

Fig. 1. Seed yield response index (SYRI) to nitrogen of some sesame varieties (ER, efficient and responsive; NER, not efficient and responsive; NENR, not efficient and not responsive)

From the present research we can derive that for obtaining high seed and oil yields of sesame, the farmers are advised to keep in mind the relationship between each of chosen variety and applied $\mathrm{N}$ amount with nutritional status of their soils. Moreover, to improve varieties of high NUE, Sohag-1 as a potent variety is considered a promising genetic tool can be inserted in sesame breeding programs.

\section{REFERENCES}

Ahmad, A., Akhtar, M., Hussain, A. Ehsanullah and Musaddique M. 2001. Genotypic response of sesame to nitrogen and phosphorus application. Pak J. Agric Sci., 38(2), 12-15.

Ahmad, R., Tariq, M., Saleem, M.F. and Ahmad, S. 2002. Comprehensive response of two sesame varieties under different row spacing. Asian J. Plant Sci. 1(5), 546-547.

Akintoye, H.A., Kling, J.G. and Lucas, E.O. 1998. N-use efficiency of single, double and synthetic maize lines grown at four $\mathrm{N}$ levels in three ecological zones of West Africa. Field Crop Res. 60(3), 189-199.

Ali, S., Jan, A., Zhikuan, J., Sohail, A., Tie, C., Ting, W., Peng, Z., Ahmad, M.I., Rahman,
M.U., Xiaolong, R., Xiaoli, L. and Yue, X.Y. 2016. Growth and fatty acid composition of sesame (Sesamum indicum L.) genotypes as influence by planting dates and nitrogen fertilization in semiarid region of northwest, Pakistan. Russ. Agric. Sci., 42(3-4), 224-229.

A.O.A.C. 1995. Association of Official Agriculture Chemists. Official Methods of Analysis $16^{\text {th }} \mathrm{Ed}$., Washington, DC, USA.

Ashri, A. 1998. Sesame Breeding. In: Plant Breeding Reviews. Janick J, ed. Oxford: Oxford. pp. 179-228

Babajide, P.A. and Oyeleke, O.R. 2014. Evaluation of sesame (Sesamum indicum L.) for optimum nitrogen requirement under usual farmers' practice of basal organic manuring in the Savanna Ecoregion of Nigeria. J. Natur. Sci. Res. 4(17), 122-132.

El-Nakhlawy, F.S. and Shaheen, M.A. 2009. Response of seed yield, yield components and oil content to the sesame cultivar and nitrogen fertilizer rate diversity. J. Environ. Agric. Food Chem. 8(4), 287-293.

Fageria, N.K. and Barbosa F.M.C. 1981. Screening rice cultivars for higher efficiency of phosphorus absorption. Pesq. Agropec. Bras. Brasilia 26, 777-782. 
Fathy, S.E. and Mohammed, A.S. 2009. Response of seed yield, yield components and oil content to the sesame cultivar and nitrogen fertilizer rate diversity. Electron. J. Environ. Agric. Food Chem. 8(4), 287-293.

Gomez, K.A. and Gomez, AA. 1984. Statistical procedures for agriculture research. John Wiley \& Sons, New York, USA.

Haruna, I.M. and Aliyu, L. 2011a. Yield and economic returns of sesame (sesamum indicum L.) as influenced by poultry manure, nitrogen and phosphorus at samaru, Nigeria. Elixir Agric. 39, 4884-4887.

Haruna, I.M. 2011b. Growth and yield of sesame (Sesamum indicum L.) as affected by poultry manure, nitrogen and phosphorus at Samaru, Nigeria. J. Anim. Plant Sci., 21(4), 653-659.

Jamdhade, K., Chorey, A., Tijare, B. and Bhale, V.M. 2017. Influence of irrigation regimes and nitrogen levels on growth, yield and economics of summer sesame. Int. J. Curr. Microbiol. App. Sci., 6(3), 2389-2393.

Jouyban, Z., Moosavi, S.G. and Seghatoleslami, M.J. 2011. Seed yield and nitrogen use and agronomic efficiency of sesame as affected by irrigation levels, nitrogen and superabsorbent. Aust. J. Basic App. Sci. 5(12), 697-702.

Kalaiselvan, P., Subrahmaniyan, K. and Balasubramanian, T.N. 2001. Effect of nitrogen on the growth and yield of sesame. Agric. Rev., 22(2), 137-140.

Kashani, H., Shahab-u-Din, Kandhro, M.N., Ahmed, N., Saeed, Z. and Nadeem, A. 2014. Seed yield and oil content of sesame (Sesamum indicum L.) genotypes in response to different methods of nitrogen application. Indian J. Sci. Technol. 9(30), 1-5.

Kathiresan, G. 2002. Response of sesame (Sesamum indicum L.) genotypes to levels of nutrients and spacing under different seasons. Indian J. Agron. 47(4), 537-540.

Le Gouis, J., Beghin, D., Heumez, E. and Pluchard, P. 2000. Genetic differences for nitrogen uptake and nitrogen utilization efficiencies in winter wheat. Eur. J. Agron. 12(3-4), 163173.

Malik, M.A., Saleem, F., Cheema, M.A. and Ahmed, S. 2003. Influence of different nitrogen levels on productivity of sesame (Sesamum indicum L.) under varying planting patterns. Int. J. Agri. Biol. 5(4), 490-492.
Minolta. 1989. Chlorophyll meter SPAD-502. Instruction manual. Minolta Co., Ltd., Radiometric Instruments Operations, Osaka, Japan.

Nakimi, M. 1995. The chemistry and physiological functions of sesame. Food Rev. Int. 11(2), 281-329.

Okpara, D.A., Muoneke, C.O. and Ojifpong, T.A. 2007. Effect of nitrogen and phosphorus fertilizer rates on the growth and yield of sesame (Sesamum indicum L). Nigerian Agric J. 38, 1-11.

Sarkar, A., Sarkar, S., Zaman, A. and Rana, S. K. 2010. Performance of summer sesame (Sesamum indicum L.) under different irrigation regimes and nitrogen levels. Indian J. Agron., 55(2), 143-146.

Sattelmacher, B., Horst, W.J. and Becker, H.C. 1994. Factors that contribute to genetic variation for nutrient efficiency of crop plants. J. Plant Nutr. Soil Sci. 157(3), 215-224.

Saudy, H.S. and Abd El-Momen, W.R. 2009. Cultural and manual weed management in sesame. J. Agric. Sci., Mansoura Univ., 34(8), 9001-9013.

Shehu, H.E., Kwari, J.D., and Sandabe, M.K. 2009. Nitrogen, Phosphorus and Potassium Nutrition of Sesame (Sesamum indicum) in Mubi, Nigeria. Res. J. Agron., 3(3), 32-36.

Shilpi, S., Islam, M.N., Sutradhar, G.N.C., Asmaul, H. and Fahmina, A. 2012. Effects of nitrogen and sulfur on the growth and yield of sesame. Int. J. Bio-res. Stress Manag. 3(2), 177-182.

Shirazy, B.J., Mahbub, M.M. and Somee, T.A. 2017. Effect of nitrogen rates and foliar spray of micronutrients on growth and yield of sesame (Sesamum indicum L.) American J. Plant Biol. 3(1), 1-21.

Silspoor, M. and Momayezi, M.R. 2006. N application management in vegetables and fruit vegetables culture. ( $1^{\text {st }}$ ed.) 38 p. Marz-e Danesh Press, Tehran, Iran.

Umar, U.A., Mahmud, M., Abubakar, I.U., Babaji, B.A. and Idris, U.D. 2012. Effect of nitrogen fertilizer level and intra row spacing on growth and yield of sesam (Sesamum indicun L.) varieties. Int. J. Agro Plant Prod. 3(4), 139144. 



\author{
نهى صلاح الدين الخولي- هاني صابر سعودي - وصفي رمضان عبد المؤمن



كجم نيتروجين/هكتار قد حقق أعلى كمية حاصل

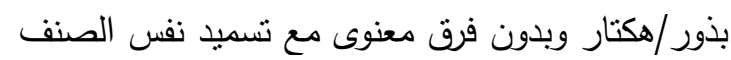


الدراسة إلى أن التكامل بين إختيار الصنف التهن المناسب

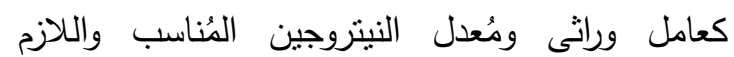

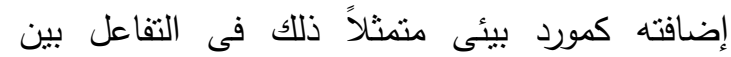

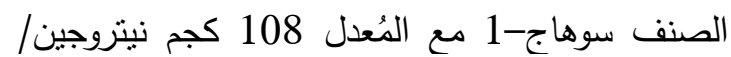

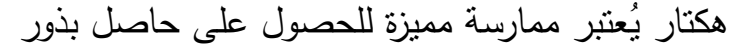

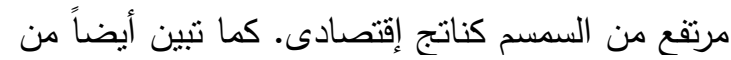
خلال دراسة دليل إستجابة حاصل أصناف السمسم

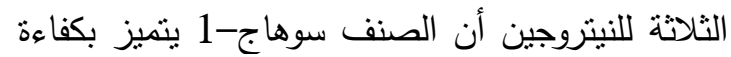



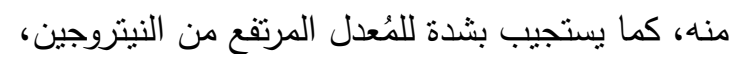

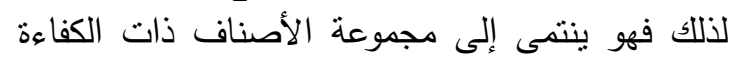
والمستجيبة للنيتروجين ER group.
الكلمات الدالة: السمسم، دليل إستجابة حاصل البذور، النيتروجين، الصنف الهن

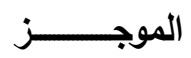

مـن منظـور بيئسى إقتصــادى أصـبـح الإسـتخدام





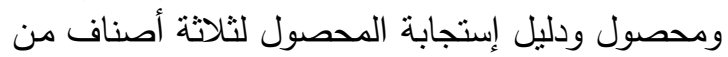

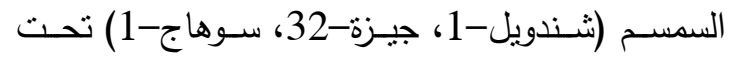

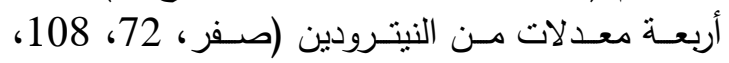

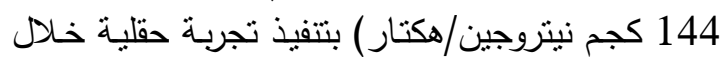
موسمى 2013 و 2014. وقد أوضحت النتائج تفوق الصنف سوهاج-14 في


هكتار . كما تبين أن تسميد نباتات السمسم بمُعدل 108 
1826

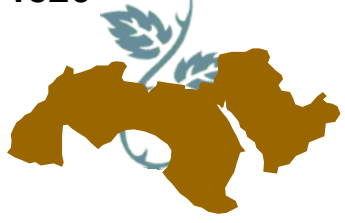

مجلة اتحاد الجامعات العربية

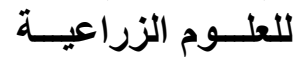

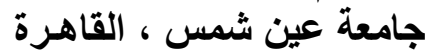

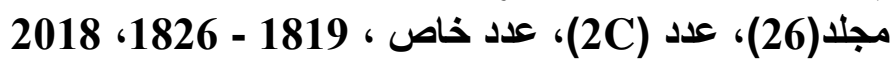

تحكيم: ا.د محمد الرفاعي البيلي

ا.د إبراهيم محمد المنولي الديد الرفي 